Georgia State University

ScholarWorks @ Georgia State University

\title{
Public attitudes towards no-vote stadium subsidies: the development and validation of an ex post proxy referendum
}

Timothy Kellison

Georgia State University, tkellison@gsu.edu

Yukyoum Kim

Seoul National University, ykim22@snu.ac.kr

Follow this and additional works at: https://scholarworks.gsu.edu/kin_health_facpub

Part of the Kinesiology Commons

\section{Recommended Citation}

Kellison, Timothy and Kim, Yukyoum, "Public attitudes towards no-vote stadium subsidies: the development and validation of an ex post proxy referendum" (2017). Kinesiology Faculty Publications. 47. doi: https://doi.org/10.1080/19406940.2016.1247106

This Article is brought to you for free and open access by the Department of Kinesiology and Health at ScholarWorks @ Georgia State University. It has been accepted for inclusion in Kinesiology Faculty Publications by an authorized administrator of ScholarWorks @ Georgia State University. For more information, please contact scholarworks@gsu.edu. 
Public attitudes toward no-vote stadium subsidies: The development and validation of an ex post proxy referendum

Timothy B. Kellison ${ }^{\mathrm{a}}$

Yukyoum Kim $^{\mathrm{b}}$

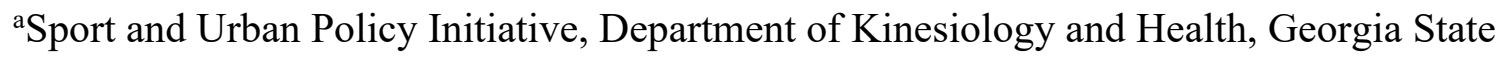
University, Atlanta, GA USA;

${ }^{b}$ Department of Physical Education, Seoul National University, Seoul, Republic of Korea 


\begin{abstract}
In most cases, professional sport stadiums are financed through a mix of public and private investment. The amount of public subsidy allocated for a stadium can vary greatly by project, as can the role of citizens in deciding such matters. With respect to public-stadium financing, research has focused chiefly on citizen participation through direct democracy (e.g., referendums and initiatives). However, the vast majority of stadium projects across North American professional sport receive public financing without any form of citizen vote. Cases of the socalled no-vote subsidy may be problematic to citizens, especially if public policy does not correspond to the public will, a fundamental principle of a democratic system of governance. Given the lack of research in this area, the purpose of this study was to develop a scale that measured citizens' attitudes toward and consequences of a no-vote stadium subsidy. In this article, we introduce the Proxy Referendum on Public Stadium Appropriation (PROPSA), a 26item instrument designed to measure seven constructs: support of financing plan, perceived stadium impact, trust in civically paternalistic leadership, team attendance intentions, congruence with democratic norms, political apathy, and voting intentions. Three associated propositions are introduced, and the scale tested using a sample of 401 voters registered in a county impacted by a recent no-vote subsidy. In the absence of a public vote, the PROPSA provides a tool for ascertaining the impact of the public will.
\end{abstract}

Keywords: public policy, political science, public subsidies, public sport facilities, scale development 


\section{Public attitudes toward no-vote stadium subsidies: The development and validation of an ex post proxy referendum}

Professional sporting arenas, ballparks, and stadiums (hereafter 'stadiums') are perpetually linked to their cities' public economies. In North America, the average public cost among the 121 facilities being used by Major League Baseball, Major League Soccer, National Basketball Association, National Football League, and/or National Hockey League teams in 2010 was US\$259 million (Long 2013). Traditionally, the allocation of public monies toward a stadium project can occur only after one of two decision-making procedures has taken place. First, and most prominent in the literature, a public referendum or initiative is held, thereby giving local citizens the opportunity to express their preferences at the ballot box (Brown and Paul 2002, Buist and Mason 2010, Dehring et al. 2008). Alternatively, policymakers may forego the tools of direct democracy, instead making the decision on their own (typically in the form of a vote among elected officials only). The outcome of this form of governing is known as a novote subsidy (Kellison and Mondello 2014).

The no-vote subsidy is a tool of representative democracies, in which citizens elect officials to govern and legislate on behalf of the polity. Indeed, while some stadium proposals necessitate a public vote because of the financing apparatus (e.g., a proposed sales tax increase), policymakers in the vast majority of cases are under no obligation to consult the electorate. In some ways, leaving public-stadium decisions to elected officials may be ideal. After all, an underlying assumption of representative democracy is that ordinary citizens generally lack the desire or means to collect the information necessary to govern effectively (Magleby 1984). Previous research on public-stadium voting behaviour suggests that, in some cases, citizens overestimate the economic benefit of a stadium development when deciding to support a public funding initiative (Santo 2007). 
In the last 10 years, no-vote subsidies have been used to publicly finance more than 35 professional sport stadiums across North America. A review of the stadium-financing literature illustrates that scholarly inquiry, though extensive, has been limited mostly to studies focusing on economics, finance, or urban regime theory (cf. Kellison and Mondello 2014). Perhaps because of the difficulty in measuring public attitudes in no-vote-subsidy cities, researchers have largely neglected discussions of these cases (e.g., Bélanger 2000, Friedman and Andrews 2011, Sam and Scherer 2010). Additionally, investigations of voter characteristics and behaviour in stadium-financing issues have failed to look beyond the outcome of a public vote.

Regardless of whether the decision to publicly finance a stadium project is arrived at through citizen vote or no-vote subsidy, both are implicitly grounded in the idea that a society should be governed by the will of its people (cf. Chaney 2014). In the case of direct democracy, citizens participate directly in the legislative process; when applied as intended, a comparison of for and against votes indicates the prevailing wishes of the citizenry (though in particular cases, the implementation of direct democracy may be more or less perfect; Fort 1999, Magleby 1984). In contrast, a no-vote subsidy is an outcome of representative democracy, in which voters elect representatives to govern on their behalves. In the absence of a direct vote on issues like publicstadium financing, it is unclear if the electorate favours or opposes such policymaking. It is also uncertain how public attitudes toward individuals, groups, and institutions (e.g., elected officials, policy benefactors, the democratic process in general) might change depending on the popularity of the no-vote subsidy. For a favourable subsidy, for example, these changes may include more favourability toward policymakers, greater support of a sports team, increased belief in democratic ideals, and lower apathy with the democratic process.

The purpose of this study, then, is to develop an instrument to measure the public's attitudes toward and responses to a no-vote stadium subsidy. Below, we outline the design and testing of the Proxy Referendum on Public Stadium Appropriation (PROPSA). This scale is 
based on the premise that even though citizens living where no-vote stadium subsidies have been awarded may be somewhat removed from the decision-making process, there are many other ways in which their opinions may be felt. Given the incidence with which no-vote subsidies are utilized by elected officials, the PROPSA is necessary for establishing whether such decisions are representative of the will of the people. With this knowledge, scholars, policymakers, and ordinary citizens can evaluate how the popularity of legislative decisions impact citizen voting behaviour, whether attitudes toward sports teams change after a stadium subsidy is awarded, and how they view the efficacy of the no-vote subsidy as a tool of democratic representation.

\section{Conceptual development}

As its name suggest, the PROPSA is intended to measure voters' attitudes toward a public-stadium finance plan in cases of no-vote subsidies. In the absence of a direct public vote by citizens, the PROPSA can be used to predict the outcome of a hypothetical referendum or initiative and, perhaps more noteworthy, examine whether that outcome leads to other long-term peripheral effects. That is, although citizen support of the financing plan has no direct authority in the decision-making process, there is still value in understanding whether a subsidy decision is popular among the polity, especially if the popularity or unpopularity of a subsidy leads citizens to modify their behaviours when it comes to attending games or voting in subsequent elections.

Though not of central focus in this study, the scale can also be used to inform policy evaluation of stadium-subsidy projects. From the perspective of team owners and policymakers, the no-vote subsidy is an efficient decision-making tool: deliberation is theoretically limited to individuals with previous experience and/or expertise in public-finance cases (Sam and Scherer 2006), and there is no need to finance a referendum campaign or pay for the actual cost of the public vote. However, no-vote subsidies, while not new phenomena, are gaining increasing notoriety for the lack of transparency often perceived to accompany these decisions (e.g., Kimes 
2014, Scherer and Sam 2008). Thus, application of the PROPSA by city and/or team officials can be used to anticipate any potential long-term consequences of a no-vote subsidy.

Included in the scale are also measures designed to assess citizens' support toward or opposition of a stadium subsidy. In previous studies, researchers have investigated demographic differences in stadium voting preferences based on a number of factors, including gender, race, age, level of education, annual family income, home ownership, and location of residence (e.g., Dehring et al. 2008, Horn et al. 2015). The PROPSA differs from earlier work by chiefly focusing on citizens' attitudinal characteristics. That is, the PROPSA contains variables in order to measure both attitudinal predictors and attitudinal changes resulting from a no-vote subsidy.

[Insert Figure 1 about here]

PROPSA constructs were selected based on a multistage conceptual model presented in Figure 1, which shows how a citizen's support of a stadium-subsidy plan is not only an outcome, but also a predictor of post-subsidy decisions. As reflected by the PROPSA constructs selected to measure citizen support of a financing plan, the process for citizens during a no-vote subsidy differs from that of a referendum or initiative. In either case, citizens consider the perceived impact of the facility; however, in a no-vote subsidy, they are expected to evaluate the trustworthiness of their elected officials to a much greater degree given the fact policymakers have full decision-making authority (Kellison and Mondello 2014). When referendums and initiatives occur, researchers are able to estimate public sentiment based on comparisons of yes and no votes cast. In the absence of such information, the PROPSA is designed in part to provide a similar indicator of voter support. Additionally, as shown in Figure 1, citizens are expected to elicit myriad responses to a stadium subsidy based on the extent to which policymaker decisions are congruent with their own preferences. In the following sections, the primary constructs of the PROPSA and related propositions are discussed in further detail.

\section{Support of financing plan}


Support of the financing plan (coded Plan) refers to a citizen's attitude toward the specific terms outlined in the stadium-financing plan. Scholars, campaign advisors, and political analysts have heavily relied on opinion polling to gauge public sentiment about policies, candidates, and issues (Erikson and Tedin 2010). Additionally, hypothetical referendums have been used to inform both the policymaking and legal processes (Vossler and Kerkvliet 2003), though they have often been employed as predictive tools prior to an actual referendum.

For elected officials, there are clear incentives for understanding whether their positions are popular among the electorate: an unpopular position on a high-importance policy can hurt policymakers' chances of being re-elected (cf. Pietryka and Boydstun 2012). For team representatives and other sport managers, gauging public support in the early stages of a stadium project can be used to identify possible sources of controversy, thereby allowing teams to proactively develop organizational perception management strategies to assuage public discontent (e.g., Kellison and Mondello 2012). Depending on the outcome of the proxy referendum, pro- or anti-subsidy groups could use the results to mobilize their respective causes; depending on the case, the poll numbers could be used to lobby policymakers to promote or contest stadium-subsidy legislation.

\section{Perceived stadium impact}

Advocates of local stadium subsidization typically justify the need for public assistance by stressing two overarching positive externalities, or benefits that extend beyond those felt by team owners and stadium operators. The first - the tangible benefits of a stadium, team, or event — consists of all the positive economic outcomes produced, including enhanced levels of regional income (Coates 2007), higher tax revenues (Dehring et al. 2008), job creation (Schwester 2007), positive public relations (Crompton 2004), and accelerated downtown redevelopment (Chapin 2004). The second - the intangible benefits of a stadium, team, or event - includes new levels of civic pride produced by improved city image (Kim and Walker 
2012) and new opportunities to develop social capital (Winfree and Rosentraub 2012). Thus, perceived stadium impact (coded Impact) is a multidimensional construct based on a voter's perception that a stadium project will result in tangible and intangible benefits to a region and its inhabitants.

\section{Trust in civically paternalistic leadership}

A second factor hypothesized to impact citizen preferences for a no-vote subsidy is related to the credibility of their elected officials (e.g., Reid 2014). Because public votes are not available for every issue, citizens entrust their elected representatives to govern in the best interests of the citizenry. However, citizens and policymakers do not always agree about what is best for the community. For example, an individual taxpayer may desire that county funds be spent to upgrade local schools, while a county commissioner may prefer to encourage growth in local industry. The county commissioner's decision to invest in industry reflects an attitude of civic paternalism, in which the authority acts in a manner that she believes is in the best interests of the whole community (Kellison and Mondello 2014).

In order for citizens to possess trust in civically paternalistic leadership (coded Trust), they need to observe two characteristics in the policymakers. First, policymakers must be perceived to possess a high level of knowledge regarding public issues. Second, this knowledge must not only inform policymakers, but it must also guide their decision-making. Thus, in order for a citizen to trust civically paternalistic leadership, policymakers must possess both knowledge and the willingness to act based on that knowledge. Unlike in other voter-support models, the integration of Trust acknowledges the critical role played by policymakers in no-vote subsidies. That is, because these government officials cast the only votes on a stadium plan, citizens are expected to weigh the trustworthiness of their elected officials when making their own judgments about a subsidy proposal. Indeed, an individual's trust in her or his government 
has been shown to influence one's degree of support for government policies (Hetherington and Husser 2012).

Based on the expectation that citizens will favour a subsidy plan that (1) they believe will produce significant benefits and (2) is promoted by trustworthy policymakers, the following proposition is put forth:

P1: Favourable perceptions toward the stadium and policymakers will have positive impacts on a citizen's support of the public stadium-financing plan.

\section{Team attendance intentions}

A stadium's primary tenant is a significant benefactor of a no-vote subsidy; the greater the public's investment in a stadium project, the lower the cost for team ownership. However, in the case of an unpopular no-vote subsidy, it is unclear whether dissatisfied citizens will assign blame to the team. Thus, in the PROPSA, we measure team attendance intentions (coded Attend), defined as citizens' expectations that they will attend a game (or games) of the stadium's primary user in the future.

Although opponents have long questioned the need for and wisdom behind stadium subsidies (Collins 2008), previous research suggests that teams enjoy a short novelty effect (i.e., rise in attendance) after a new facility opens (Coates and Humphreys 2005). While studies have shown that this effect exists in both publicly and privately funded stadiums (Zygmont and Leadley 2005), the recent opening of Marlins Ballpark in Miami — and the subsequent lack of a marked increase in attendance — suggests that an unpopular stadium-finance plan can impact the favourability or unfavourability of the facility's primary tenant (Hanks 2013). The Marlins' abbreviated novelty effect is surely the result of many factors (e.g., team record, outcome uncertainty, size and quality of the stadium, playing styles; Ahn and Lee 2014), but the lack of interest from nonfans and casual fans is also worthy of consideration (Coates and Humphreys 2005). Previous research has shown that professional sports teams are aware of the opportunity 
to connect to prospective consumers based on stadium enhancements and strategic initiatives (Kellison and Kim 2014), and failing to build excitement — or worse, generating ill feelingstoward a new stadium may limit a team's ability to connect to citizens who otherwise might not consider visiting the new facility.

\section{Congruence with the electorate}

In order for citizens to consider an act congruent with the electorate (coded Congruent), they must perceive public policies to be an accurate reflection of the will of the people. As noted by Grimes and Esaiasson (2014), this congruence is "integral to representative democracy" (p. 758). As only one potential marker of government responsiveness, congruence between public policy and public opinion can be difficult to measure (Warwick 2015). In previous research, scholars have suggested that congruence can fluctuate with the electoral seasons, as voters may use an election to "reset" an unresponsive government (though this fluctuation is moderated by a number of factors, including electoral systems; Soroka and Wlezien 2015). As discussed previously, the will of the people may be expressed either directly through the initiative or the referendum, or indirectly through elected representation. Although past research in the political science literature has examined the relationship between democratic incongruence and voter apathy, such lines of inquiry have not often utilized survey research methods. We expect that citizens who support the financing plan will consider the policymaking process to be aptly democratic, whereas those who do not support the plan will consider the process to be undemocratic. This belief is informed by the literature on projection bias, which generally holds that individuals tend to believe that their personal preferences are shared by most others (Van Boven et al. 2012).

Based on the rationales provided above, we offer the following proposition:

P2: Citizen support of the public stadium-financing plan will have a positive impact on citizen's attitudes toward the stadium tenant and the democratic process in general. 


\section{Political apathy}

In cases where policymakers proceed with a no-vote subsidy despite the opposition of the majority of the electorate, local citizens may begin to question the value of their own democratic participation. Apathy has been defined as either 'a particular state of mind wherein there is a lack of feeling, passion or interest, or as a type of behaviour indicating the lack of participation and lack of action' (Davis 2009, p. 152). For the purposes of scale development and our interest in voter opinions, we incorporated the former, attitudinal characterization in the definition of political apathy (coded Apathy): the absence of feeling, passion, or interest toward political issues.

Several factors may contribute to the formation of political apathy. Emmerson (2012) argued, 'if governance is poor in a democratic polity, the legitimacy...of democracy is more likely to be jeopardized' (p. 62). Citizens may respond to a state's poor governance in a number of ways; while some may actively protest, others may simply grow apathetic (Useem and Useem 1979). This passivity stems from an individual's sense of powerlessness (Rosenberg 1951) when it comes to influencing public policy. An unpopular no-vote subsidy may create apathy among the citizenry if they feel they have no impact on public policy. As discussed below, an alternative reaction is political alienation.

\section{Voting intentions}

A key difference between apathy and alienation is that apathetic citizens disengage from political participation, while alienated citizens are empowered to induce change (Thompson and Horton 1960). The idea of a simultaneously alienated and empowered citizen is supported by previous research on voter behaviour, which has shown that voter turnout increases when a local government is perceived by its electorate as unresponsive to public needs (Sinclair et al. 2011). Additionally, as referenced by Useem and Useem (1979), dissatisfied citizens may respond to an inadequate government by engaging further in the political process. 
As discussed in the above sections, previous research has shown that citizens can respond in widely divergent ways based on their assessment of the policymaking process. This expectation is summarized in the third proposition:

P3: A citizen's assessment that the local political process is congruent with the electorate will have an impact on her or his future political participation. Citizens who deem the decision-making process to be congruent might not experience any changes to their levels of political apathy, while those who believe the process is flawed could become more apathetic.

\section{Methods}

\section{Item screening}

After defining the constructs of interest, it became necessary to develop a measurement instrument. When previously validated items were not available, new items were developed. As part of the item-generation and scale-development phases, we generated an initial pool of 81 items, and these items were reviewed by a panel of six experts, all of whom were researchers with records of publication and experience in scale development. After the initial item review, we revised the items to reflect the recommendations of the panel and resubmitted the pool of items. This process was repeated two additional times, and after the fourth review, an instrument of 38 items was prepared for pilot testing. These items are described below. For a list of the finalized 26 items, refer to Table 1.

Plan

To measure support of a financing plan, five items were proposed following standard protocols used in opinion polling (cf. Sonck and Loosveldt 2010, Woods 2006). While written generically, each of the items could be tailored to the specific financing details of a no-vote subsidy plan. It is important to acknowledge the possibility that a citizen may not be adequately informed when judging the merit of a stadium subsidy. As noted in the introduction, previous 
research has shown that individuals can overestimate the anticipated economic benefit of a stadium development (Santo 2007). Furthermore, citizens may use so-called information shortcuts to evaluate complex financing plans using the lens of the media and through their dayto-day experiences (Mondello and Kellison 2016). Still, regardless of the sources of a citizen's information, the Plan construct provides an indicator of an individual's general favourability of the plan.

Impact

Because of its multidimensionality, the perceived stadium impact construct is measured in a manner that considers both the tangible and intangible benefits of the facility. The literature has provided a lengthy list of these supposed benefits, and it provides a foundation for the generation of items for the PROPSA (e.g., Groothuis et al. 2004, Johnson et al. 2001). To narrow the list of benefits, we reviewed both the primary articles and reader responses appearing on the websites of prominent media entities regarding a recent no-vote subsidy (see 'Context' section for more details). Previous analyses of stadium-financing cases have highlighted the media's significant role in informing citizens (Buist and Mason 2010). The press has also been influential in educating voters about candidates and policy issues (Smith and Tolbert 2004).

In total, 10 projected tangible and intangible benefits emerged from the content analysis. The stadium's expected tangible benefits included: job creation; anchoring a larger stadium district; housing a professional sport team; attracting business to the city; and contributing to growth in the area surrounding the facility. The facility's anticipated intangible benefits included: instilling civic pride among locals; providing the city with major-league status; adding vibrancy to the area surrounding the stadium; and revitalizing a blighted area.

Although scholars investigating the economic impact of stadiums have often delineated between tangible and intangible benefits, it is less necessary to make this distinction when measuring voter attitudes, as individual citizens are unlikely to view the two as unique concepts 
because several of the benefits are closely intertwined. For example, while the major-league status of a city may simply be a point of pride among locals, this status may also increase the city's exposure to potential business opportunities. Indeed, in both the arguments supporting and opposing the stadium-financing plan appearing in the local media, there was no delineation between tangible and intangible benefits. In the voter's mind, a stadium's value can be expressed in both economic and non-economic terms, with varying weights assigned to the individual benefits.

Trust

Research centring on political science and voter behaviour has examined factors contributing to myriad voter attitudes toward government, including distrust and cynicism (cf. Caldwell 2006), and these constructs closely relate to trust in civically paternalistic leadership. Despite the link, the items used to measure voter attitudes have not specifically examined the concept of civically paternalistic leadership (e.g., 'There is one law for the rich and one law for the poor'; Schoon and Cheng 2011). Therefore, to measure an individual's trust in civically paternalistic leadership, original items were developed in this study. A key premise of these items was that an individual's trust in civically paternalistic leadership is a generic and relatively stable trait. This assumption was based on previous research that has shown that an individual's political trust forms at an early age and changes only minimally in one's lifetime (Schoon and Cheng 2011). To measure an individual's trust in civically paternalistic leadership, six original items were proposed.

Attend

To determine the extent to which citizens intend to engage in consumer behaviour, each individual's self-reported attendance intentions was collected using four items. Three items originated from Kim et al. (2011), who compiled these items from previous literature, and then made modifications when necessary. In Kim et al.'s investigation, this construct showed 
satisfactory psychometric properties, with a reliability coefficient value of .97 and average variance extracted value of .91 .

\section{Congruent}

The five items developed to measure the democratic congruence construct in this study captured the general idea that the public voice should be first recognized, and then followed. For example, "If given the opportunity, I think the majority of [voters] would have voted "yes" to [finance the stadium].'

Apathy

To measure Apathy, four items were replicated from Pinkleton et al.'s (2012) investigation of how cynicism and scepticism toward U.S. politics contributed to apathy. Their instrument contained four items to measure apathy, which showed evidence of internal consistency in their study $(\alpha=.70)$.

Vote

As noted previously, an alternative reaction to political apathy is political alienation, the consequence of which could include 'an undirected vote of resentment or an organized vote of opposition' (Thompson and Horton 1960, p. 190). In sum, four items were developed to measure Voting Intentions (coded Vote).

Demographic characteristics

Premised on previous research showing demographic differences in stadium-subsidy voting outcomes (Dehring et al. 2008), individual characteristics were also collected in this study. As discussed previously, researchers have investigated differences in stadium voting preferences based on gender, race, age, level of education, annual family income, and location of residence. Each of those demographic factors were included in the PROPSA to determine the extent, if any, to which individual characteristics influence voters' preferences regarding public stadiumfinancing issues. 


\section{Format}

In sum, the initial survey developed for this study contained 47 items, including one qualifying item, seven items measuring demographic characteristics, 38 items measuring seven latent constructs, and one open-ended question for participant comments. As discussed earlier, the instrument contained a combination of items existing from previous instruments and newly generated items. In all cases of previously used items, the original rating scale was used in this survey. Response options to demographic characteristics were consistent with those provided in the most recent U.S. Census.

Survey participants responded to the items using a 7-point, Likert-type scale. This scaling system was consistent with the majority of previously used items. In the cases of perceived stadium impact, trust in civically paternalistic leadership, support of financing plan, team attendance intentions, congruence with the electorate, and political apathy, the items used the anchors strongly disagree and strongly agree.

\section{Context}

To test the psychometric properties of the scale used in the PROPSA, the instrument was administered in the county of a recent no-vote stadium subsidy in the United States. In this particular case, members of the city council and county commission voted in favour of a plan to use publicly generated revenues to finance the purchase of a privately owned, multipurpose arena. The arena is home to a professional sport team and is the centrepiece of a large entertainment district containing residences, corporate offices, other sport and entertainment venues, and restaurants and bars. Although no new taxes were raised to finance the no-vote subsidy, opponents of the plan argued that the public monies earmarked for the arena purchase could instead be used to improve existing infrastructure, resurface roadways, or support public education. 
Though the specifics of the deal are unique from others, the above financing case is among the most recent examples of the no-vote subsidy. In instances of the no-vote subsidy, policymakers direct public funds toward a stadium without the expressed approval of local citizens. As discussed previously, this policymaking process is standard in a representative democracy: after all, decision-makers are elected to legislate on behalf of the polity. Still, in cases where policymaking does not reflect public sentiment, citizens may-with varying levels of merit - accuse elected officials as acting in their own interests (Delaney and Eckstein 2003), or more broadly, point to the dysfunctional and uncompromising nature of government (Abramowitz 2013). In the case of the former, the absence of public approval may not align with the ideals of a modern democracy, in which the will of the people is expressed either directly (via initiative or referendum) or through elected representatives. Attitudes toward and consequences of the no-vote subsidy are the subject of the PROPSA, the development and testing of which is described below.

\section{Pilot Study}

Prior to the main test administration, we pilot tested the scale for several reasons, as recommended by Groves et al. (2004): to examine the psychometric properties of the preliminary pool of items; to assess the variability in outcome measures that assisted in determining the sample size for the main study; and to identify problematic areas related to instrument design, item construction, and sampling method. Such preliminary analyses were necessary in order to purify and refine the survey prior to conducting the principal study.

\section{Design}

We administered the pilot study through the medium of internet survey due to the low cost of administering, the relative ease through which participants could be recruited, and the low environmental impact. Additionally, the online-survey format provides greater ease of use for participants when responding to qualifier and contingency questions. Instrument design was 
guided by Dillman et al.'s (2008) web-survey construction principles, which acknowledge the advantages of online questionnaires and provide suggestions for reducing the occurrence of measurement and nonresponse errors.

In recognition of the possibility of biasing effects resulting from measuring multiple constructs in a single survey administration, we followed several procedural and statistical steps suggested in prior literature (Podsakoff et al. 2012) to mitigate the inflation associated with common method variance (CMV). For example, care was given to create proximal separations between the predictor and criterion variables. As Podsakoff et al. noted, however, the ability to create such separations is contingent upon the length of the survey and the desired randomness of the items, and each of these characteristics influenced the distance between the predictor and criterion variables. Additionally, during the instrument development stage, items were drafted in ways that reduced the ambiguity of their meanings; for example, indeterminate words (e.g., many, sometimes) were substituted with specific words (Johnson, 2004). When respondents suspect a response choice is socially desirable, their answers are more likely to be biased; therefore, where possible, the social desirability of the items have been minimized. Finally, items were constructed so that a balance between positive and negative responses would be expected. As noted by Podsakoff et al., an instrument that contains a mix of positively and negatively worded items reduces acquiescence (i.e., positively biased) and disacquiescence (i.e., negatively skewed) response patterns.

\section{Participants and sampling}

We utilized a purposive sampling technique for the pilot study. The objective of this technique was to enlist a sample of participants possessing a wide array of awareness of and attitudes toward the local no-vote subsidy described previously. We recruited participants through personal invitation on various social networking sites, including Facebook and Twitter, and news and message board website that focused on community issues. Additionally, we 
contacted and enlisted instructors and professors of sport management, public policy, and political science classes at nearby colleges and universities to disseminate the survey information to their students. A total of 171 individuals completed the pilot survey. Upon review of the data, we removed 13 cases due to incompleteness, resulting in a usable sample size of $158(92.4 \%)$.

\section{Data analyses and results}

In our evaluation of the scale, the decision to retain or drop an item was based on an assessment of psychometric properties, the theoretical relevance of the items, and the parsimoniousness of the scale. To evaluate the psychometric properties of items, we conducted confirmatory factor analysis (CFA) using Mplus 7.0 (Muthén and Muthén 2012). In our analysis of the pilot study's constructs and items, the model yielded acceptable fit ( $\mathrm{S}-\mathrm{B} \chi^{2} / \mathrm{df}=$ $1443.43 / 758=1.90, \mathrm{CFI}=.90, \mathrm{SRMR}=.06, \mathrm{RMSEA}=.08, \mathrm{WRMR}=1.07)$. All factor loadings were significant in the predicted direction. However, several factor loadings were lower than .70, suggesting the scale's performance could be improved by removing those items. Based on factor loadings, item-to-total correlations, and item correlations, Apathy failed to meet the .70 standard $(\mathrm{r}=.43)$ and multiple items suffered from low ITT and/or item correlations; ordinarily, researchers may choose to remove or modify such items. However, in light of the constructs' theoretical relevance and the desire for scale parsimoniousness, we retained several items for future analyses (discussed later). At the conclusion of the pilot study, 11 items were dropped, leaving a total of 26 items: Impact (five items), Trust (four items), Plan (four items), Attend (two items), Congruent (four items), Apathy (three items), and Vote (four items).

\section{Principal study: Validation of the PROPSA scale}

Following the pilot data collection and initial reliability testing, we collected new data, completed another assessment of the instrument's reliability, evaluated the evidence of validity, and developed norms. The theoretical framework summarized in Figure 1 informs a nomological network against which psychometric properties, including convergent and discriminant validity, 
are assessed. Thus, the primary purpose of the main study was three-fold: to confirm the hypothesized factor structure of the PROPSA scale, to provide empirical evidence of reliability and validity for the scale, and to detect the possible presence of population heterogeneity in the factor structure.

\section{Design}

Upon analysis of the pilot study data and instrument refinement, we developed a paper and-pencil mail survey to administer the PROPSA. The scale was included in a survey packet that also contained a cover letter, a raffle entry form, and a postage-paid business reply envelope. As discussed previously, steps were taken to reduce the influence of CMV, which could inflate relationship estimates among the variables due to the measurement of multiple constructs in a single instrument (Podsakoff et al. 2012).

\section{Participants and sampling}

We used a simple random sampling technique. We obtained records from the local elections board, which provided contact information (including names, addresses, dates of birth, voter registration dates, and previous elections participated in) of more than 800,000 registered voters in the county of interest. While all records represented registered voters, included in this number were inactive registered voters. According to the county elections board, inactive voters were classified as any individual who met at least one of three criteria: (1) the voter had neither re-registered nor voted during the past two federal election cycles (a total of eight years); (2) the voter's address was listed on the U.S. Postal Service's National Change of Address database; or (3) the voter registration acknowledgement card sent to confirm a voter registration was returned as undeliverable. In an effort to reduce the likelihood that PROPSA mailings would be returned, we removed over 180,000 inactive voters from the pool. Each of the remaining cases was assigned a random number generated in SPSS Statistics 20. Finally, 5,000 records were selected from this pool for inclusion in this study, 400 of which were returned as undeliverable. From the 
remaining pool of 4,600 voters, 401 individuals returned complete and usable surveys, resulting in a final response rate of $8.7 \%$.

In terms of demographic characteristics, the median age of PROPSA respondents was 52, and over one-fifth of all respondents were 65 years old or greater. The female-to-male ratio was nearly even, with female persons representing $49.9 \%$ of the sample. The vast majority of respondents self-identified as White $(85.8 \%)$. Over half of the sample held at least a bachelor's degree, and $26.9 \%$ reported possessing a graduate degree or higher. The median per capita income range was US\$50,000-74,999, and 98.3\% of all respondents voted in the 2012 general election, as verified by the county elections board.

The characteristics of the sample were compared with available demographic data on all registered voters in the county (i.e., age, participation in 2012 U.S. general election) and all county residents (i.e., age, gender, race, level of education, participation in 2012 U.S. general election). In the absence of key demographic information about registered voters in the county, we are limited in our ability to determine whether the sample is consistent with the demographic characteristics of county residents in general. In general, the sample was consistent with the county population based on gender. On the other hand, the sample was older and had received a higher level of formal education. Differences between voters in our sample and county residents in general should be unsurprising considering the typical demographic trends among registered voters in the US. For instance, the more a citizen ages, is educated, and earns, the more likely she or he is to be a registered voter (File and Crissey 2012).

\section{Data analyses and results}

We conducted CFA to assess the psychometric properties of the scale using Mplus 7.0. We first evaluated the key assumptions about the data. The positive sign of the determinant of all input matrices indicated that severe multicollinearity or singularity was not present. Normalized Mardia's (1985) coefficients of skewness and kurtosis were $200.70(\mathrm{p}<.001)$ and $139.74(\mathrm{p}<$ 
.001), respectively. These results indicated a lack of multivariate normality. Thus, we adopted the Satorra-Bentler (S-B) scaling method for CFA and subsequent SEM analysis. Accordingly, when conducting $\chi^{2}$ difference tests, we adjusted the S-B $\chi^{2}$ statistics using the formula provided by Satorra and Bentler (2001).

Values of selected indices from CFA indicated good overall fit of the measurement model to the data $\left(\mathrm{S}-\mathrm{B} \chi^{2} / \mathrm{df}=431.40 / 303=1.42 ; \mathrm{RMSEA}=.03,90 \%\right.$ CIRMSEA [.03, 04]; CFI $=.98 ; \mathrm{SRMR}=.04 ; \mathrm{WRMR}=.88)$. The results from the initial run suggested that items used to measure Team Attendance might be redundant. The loadings of two items were .99 and reliability coefficients were .98 . Therefore, we shortened the scale following DeVellis' (2012) suggestion to reduce the number of items when reliability coefficients greatly exceed .90 and the items are considered redundant.

The revised model yielded good fit to the data $\left(\mathrm{S}-\mathrm{B} \chi^{2} / \mathrm{df}=398.59 / 278=1.44 ; \mathrm{RMSEA}=\right.$ $.03,90 \%$ CIRMSEA $[.03,04]$; CFI $=.98 ;$ SRMR $=.04 ;$ WRMR $=.86)$. All reliability coefficients of the constructs exceeded .70, ranging from .77 to .97 . Additionally, as shown in Table 1, all factor loadings were significant in the predicted direction $(\mathrm{p}<.001$; loadings ranging from .63 to .98 ), and all of the average variance extracted (AVE) values were greater than .50 (ranging from .58 to .93). Thus, the measures demonstrated evidence of good convergent validity and reliability. Discriminant validity was examined for each construct by performing multiple $\chi^{2}$ difference tests of unity between all pairs of constructs. The unconstrained model (i.e., correlation estimated freely) was significantly better than the constrained model (i.e., correlation between a pair of latent factors constrained as 1) in all comparisons (the smallest adjusted $\Delta \mathrm{S}-\mathrm{B}$ $\chi^{2}$ was 496.26, $\left.\mathrm{p}<.001\right)$. In addition, AVE values for all constructs were larger than the corresponding squared inter-construct correlations (see Table 2). Overall, the results indicated that the measures possessed adequate psychometric properties. 
[Insert Table 2 about here]

We conducted a factor mixture analysis to test possible population heterogeneity caused by unobserved sources. Estimation of the hypothesized model with a single class terminated normally and provided the following model fit information: loglikelihood $\mathrm{H}_{0}$ value = 13134.058, $\mathrm{BIC}=26466.115$, and $\mathrm{ABIC}=26861.518$. Estimation of the model setting factor loadings free across two-latent classes terminated normally and yielded the following model fit information: loglikelihood $\mathrm{H}_{0}$ value $=-13032.476, \mathrm{BIC}=26354.952$, and $\mathrm{ABIC}=26934.077$. The difference in $\mathrm{BIC}$ and $\mathrm{ABIC}$ values between the single-class model and the two-latent-class model was marginal. Moreover, the $p$-value of the Lo-Mendell-Rubin adjusted likelihood ratio test was insignificant $($ ALRT $=202.429, p=.71)$, indicating the model was not significantly improved by adding a class with more parameters.

This non-significant result favours the single-class model for several reasons. From a statistical standpoint, the more parsimonious model (i.e., in our case, the single-class model), has withstood a higher chance of rejection than a less parsimonious model (Raykov and Marcoulides 1999). From a theoretical standpoint, a parsimonious model is more desirable since the virtue of a conceptual model is its simplicity to the extent that it does not leave out essential information that is needed to explain phenomena while still fitting the data reasonably well (Shugan 2002). This result suggests that there was no unobserved source introducing significant population heterogeneity in the factor structure of the PROPSA. Altogether, the results provide support for the external validity of the PROPSA within the sample used, suggesting the scale reliably measured the constructs that the scale was intended to measure across different subpopulations.

We tested the nomological validity of the constructs using simultaneous equations. The global fit indices indicate that the hypothesized model is consistent with the data $\left(\chi^{2} / d f=\right.$ $477.07 / 291=1.64, \mathrm{RMSEA}=.04, \mathrm{CFI}=.97, \mathrm{SRMR}=.07, \mathrm{TLI}=.97)$. The path from Impact (standardized $\gamma=.47, S E=.05$ ) and Trust (standardized $\gamma=.26, S E=.05$ ) to Plan were 
significant. Plan had a significant impact on Attend (standardized $\beta=.40, S E=.04$ ) and Congruent (standardized $\beta=.74, S E=.03$ ) were significant. The path from Congruent to Apathy was also significant (standardized $\beta=.15, S E=.05$ ). Lastly, the relationship between Apathy and Vote was negative and significant (standardized $\beta=-.46, S E=.04$ ).

\section{Discussion}

The purpose of this study was to design and test a proxy referendum in order to better understand the reactions of ordinary citizens to no-vote stadium subsidies. Two objectives guided this empirical examination: first, to consider the factors that influence a citizen's attitude toward a no-vote financing plan; and second, to examine public reactions to such public policies. After defining the constructs of interest and generating a preliminary list of measurement items, the pilot and principal tests were conducted. In the remaining sections, we discuss the appropriateness of the PROPSA as an instrument for investigating public attitudes toward novote stadium subsidies. Additionally, we comment on the study's implications and offer several suggestions for future research.

\section{Future considerations with the PROPSA}

As is the case in scale development projects, researchers should continue to evaluate the psychometric properties of the PROPSA in future work. The empirical results suggested that items used to measure Team Attendance Intentions might be redundant. As noted previously, the loadings of two Attend items were .99 , while the reliability coefficient was .98 . While the decision to reduce the set of items was adequate for the purpose of this study (i.e., to measure the unidimensional Team Attendance Intentions subscale; DeVellis 2012), it would be fruitful to develop a set of items to measure various aspects of Team Attendance Intentions for the future.

A second construct worth further attention was Political Apathy. While the items have shown evidence of internal consistency in previous work (Pinkleton et al. 2012), it failed to meet the .70 standard in this study. As noted further in a later section, with a sample more evenly 
distributed between voters and non-voters, more indication of citizen apathy and efficacy in the democratic process may be discerned, especially considering the fact that the low correlations between Apathy and Vote and other variables were consistent with the theoretical framework and nomological network. Alternatively, it may be beneficial to revise or reconstruct a measure of attitudes toward the democratic process. If a voter felt the decisions being made by elected representatives were unreflective of the common will, it might not change the perceptions that participating in elections took too long or was too much trouble (as measured by Apathy1 and Apathy4, respectively). Moving forward, two additional measures worthy of consideration are democratic apathy and political efficacy (American National Electoral Studies 2012).

Additional consideration of the proposition 1 could enhance studies utilizing the PROPSA. In its current form, two variables were used to predict a citizen's support of a stadiumsubsidy plan. While the first variable - Impact — focused entirely on qualities of the stadium itself, the second variable — trust—focused entirely on qualities of elected officials. The intent of this two-predictor proposition is to measure the possibility that citizens evaluate an issue based not only on its particular details, but also on the trustworthiness of the elected representatives. For example, in a no-vote stadium subsidy that was attracting negative attention from citizens (e.g., protests, critical media attention), the source of their discontent might be more related to the perceived untrustworthiness of city councilmembers (i.e., the decision makers) than concerns over the stadium plan itself. Still, additional items that measure the negative externalities (e.g., air, noise, and light pollution; increased traffic; loss of urban space; Mondello et al. 2009) of a proposed project could yield further insight.

It is also worth acknowledging the possibility that individuals who responded to the survey had particularly strong opinions (either favourably or unfavourably) toward the stadium finance plan, while those without much knowledge of or interest in the case refrained from completing the surveys. Such a trend would mimic voters' general electoral tendencies, as 
previous studies of voter turnout have shown that citizens are more likely to participate in a public vote when they find a candidate to be especially favourable or unfavourable (Harder and Krosnick 2008). Additionally, political campaigns that invoke strong feelings against a poorly performing incumbent policymaker can generate surges in voter registration and actual voting (Brader 2006). Thus, just as apathetic voters are less likely to cast votes in a local election, we expect citizens who are apathetic toward a public-financing plan to be less likely to return surveys. In the future, researchers hoping to capture a larger sample of apathetic voters might consider a stratified sampling technique.

Finally, while the PROPSA was developed with the intent of measuring the relationships between its constructs (such as the relationships portrayed in Figure 1 or others), the scale could also be utilized longitudinally to identify changes in citizen attitudes throughout a stadium development process, the phases of which might include negotiation and deliberation, appropriation, construction, and completion. Through a longitudinal tracking approach, researchers could identify whether citizen attitudes are relatively stable or fluctuate over time.

\section{Implications}

The PROPSA is designed to allow for large-scale analyses of voter attitudes toward myriad individuals, groups, and institutions. In brief, the instrument can be used to test whether ordinary citizens reflect upon both the perceived impact of a sport stadium and the trustworthiness of their elected officials when considering the appropriateness of a stadium subsidy (as measured by Perceived Stadium Impact and Trust in Civically Paternalistic Leadership, respectively). Furthermore, researchers can determine how a citizen's approval or disapproval of a financing plan can impact attitudes toward the team, policymakers, and the democratic process altogether. In cases in which a citizen might disapprove of the means or outcome of a no-vote subsidy, however, it is currently unclear whether it influences her political apathy or future voting intentions. Using the PROPSA, further investigation can determine if a 
citizen's strong support or disapproval of a no-vote subsidy compels the individual to actually vote for or against the policymakers affiliated with a public-financing plan.

First, in future applications of the PROPSA, researchers should endeavour to increase the survey response rate. In this study, the usable response rate $8.7 \%$; however, this low rate was unsurprising, given the low response rates normally attributed to mail surveys (Griffis, Goldsby, and Cooper 2011; Visser et al. 1996). Interest in completing the survey might have also declined as a result of the high volume of political mailings and other election-related communication received by county residents during data collection, which coincided with a major U.S. general election. As noted by Bialik (2012), opinion pollsters faced steady declines in response rates throughout the campaign. Based on our experience, the response rate would be greatly enhanced by specifically targeting involved voters (i.e., those with previous voting activity and future voting intentions; Murray, Riley, and Scime, 2009). In this study, 98\% of the sample has participated in the previous U.S. general election, compared with $71 \%$ of registered voters in the county and $64 \%$ of voting-aged county residents. Thus, it appears that targeting politically involved voters would yield greater response rates.

The PROPSA can be utilized to extend what we know about voters in specific stadiumfinancing cases. As noted previously, there has been little effort to ascertain the views of ordinary citizens in cases of no-vote subsidies. Furthermore, previous research on all forms of stadium subsidies has focused on either the voting outcome or political consequence. A key premise of the PROPSA is that, in addition to favouring a stadium-finance plan itself, citizens may connect the plan to others, thereby influencing their attitudes toward policymakers, the benefiting team, and democracy in general.

For elected officials involved in no-vote subsidies, deciding to allocate millions of public dollars toward a stadium project may be politically risky, particularly if a subsidized stadium project fails to produce the benefits often championed by proponents. An unpopular no-vote 
subsidy can come back to haunt supportive policymakers in future elections. Such was the case in Miami, where a campaign to remove mayor Carlos Alvarez brought attention to his allocation of US\$370 million toward Marlins Ballpark without holding a public vote (Recall Mayor Alvarez 2011). Interestingly, citizens relied on a third type of direct democracy — the recall— to successfully remove Alvarez from his executive position (Haggman and Brannigan 2011).

In addition to policymakers, sport managers could also benefit from understanding the political consequences of a no-vote subsidy. Based on several high-profile examples of public unease over stadium-subsidy issues (i.e., Seattle's stadium subsidy ban, Kowal 2006; Olympic referendum defeats across Europe, Clarey 2014; Obama's budget proposal to disincentivise stadium subsidies, Office of Management and Budget 2015), sport organizations may find themselves facing increasing opposition when pursuing new sports facilities. But, by understanding how policymakers can promote a stadium subsidy while avoiding political fallout, sport managers may be able to leverage political support for a publicly funded stadium. For example, if unpopular stadium subsidies are found to be inconsequential to policymakers' political careers, pro-subsidy stakeholders (including professional sports teams) could advocate for public financing through a no-vote subsidy, thereby saving the team from financing a costly stadium campaign (e.g., Blair and Swindell 1997).

Professional sports teams face particular challenges during the stadium-subsidy debate. When the threat of franchise relocation is not credible, a team may choose to insulate itself from the political process, as distancing wealthy stakeholders such as team owners from a pro-subsidy campaign can be an effective way to manage public perceptions (Blair and Swindell 1997). However, this isolation strategy limits the organization's ability to manage its public perception, which may become necessary if the no-vote subsidy is especially unpopular among local citizens. In this case, timing a perception-management initiative to coincide with the announcement of a no-vote subsidy may be most effective. Based on proposition 1, teams seeking to maintain or 
gain the public's favour must be cognizant of the need to promote both the positive impact of the new stadium and the trustworthiness of policymakers associated with the no-vote subsidy.

A portion of the PROPSA is also designed to measure how a citizenry's attitude toward the democratic process may be influenced by a no-vote stadium subsidy, particularly in cases in which a majority of voters are unsupportive of a public-financing plan. As discussed previously, when citizens believe their elected officials have become out-of-touch with their electorate, some voters may respond in subsequent elections by voting for a candidate who challenges the incumbent. On the other hand, other voters might become disenchanted with politics, thus withdrawing from the democratic process altogether. Because this apathy threatens the efficacy of a democratic polity, citizens concerned with increasing political participation in a city or region may be especially interested in the results of a study utilizing the PROPSA. Despite the considerable diversity among the classical political thinkers, a common theme inheres in nearly all models of democracy, including those of Thucydides, Plato, Machiavelli, Locke, Jefferson, and Madison: the ideal society is one governed by the people, but in order for that form of government to be fully realized, citizens must be informed and actively involved in the affairs of the community (Held 2006). Therefore, measuring voter attitudes toward a specific policy and democracy more generally provides a look into how stadium politics and citizenship may be intertwined.

\section{Directions for future research}

The adoption of the PROPSA in subsequent research projects would serve two primary purposes. First, scale items could continue to be refined, while new constructs could be proposed to improve the measurement of citizen attitudes toward no-vote subsidies. Currently, much of the focus of the PROPSA is on the political and democratic ramifications of the no-vote subsidy. An additional purpose of this line of research, however, is to examine the business impact of the novote subsidy on a stadium's primary tenant; future research should further explore the connection 
between the team and stadium subsidy. For example, researchers should consider the perceptionmanagement strategies of teams involved in stadium-subsidy debates and identify the prevailing messages produced by owners and team management, from whom these messages originate, and to whom these messages are directed.

In this study, we identified two antecedents of a citizen's support of a stadium-subsidy plan—-belief that the project will have a positive impact and trust in elected leadership — but other factors could certainly influence one's support of a plan. A comprehensive list of influential factors would likely include the public-private cost ratio; the degree to which information sources are impartial (Crompton 1995, Mondello and Kellison 2016); the extent to which the public is engaged in and informed on the issue (e.g., rational ignorance; Arnold 2012, Downs 1957); and the influence of special-interest groups, growth coalitions, and political leaders (Friedman and Mason 2005).

Second, future investigations must consider the very questions that prompted the development of the PROPSA scale: in the case of a no-vote stadium subsidy, does public policy reflect the will of citizens, and if not, is there a cost to this decision-making process? Through the use of a proxy referendum such as the PROPSA, researchers can hypothesize whether voters would have approved a public stadium-finance issue at the ballot box. Additionally, examining the relationships outlined in the conceptual model will yield new insight on the consequences - if any —of a no-vote subsidy. For scholars of multiple disciplines, journalists, elected officials, sport teams and stadium owners, and ordinary citizens, the outcome of such an investigation would be noteworthy. For example, a study that found that a majority of citizens would have rejected the terms of a no-vote subsidy during a public vote might inspire local dialogue about the utility of the democratic process, the nature of elected representation, and the value of professional sport stadiums to their communities. As data from stadium referendums and 
initiatives become less and less common, the PROPSA provides researchers with a tool through which issues of public policy and public-stadium finance can continue to be studied.

Third, the possible maximum points (i.e., 7) of the four items for Voting Intentions were within one standard deviation of the mean, which makes discrimination among the participants at the top end of the scale unclear. Therefore, it would be beneficial to validate the psychometric properties of the items using a sample with greater variability in scores between participants in future research.

Lastly, approaching the issue of public-stadium finance with an emphasis on democracy may create new opportunities for interdisciplinary research that draws from political science and public administration. Given the charge for sport management scholars to establish and engage in interdisciplinary collaboration (cf. Doherty 2012; Tutka and Seifried 2015), future work should solicit experts from multiple corners of the academy. In many ways, research on public-stadium finance has already drawn from outside the sport management discipline, including economics (e.g., Coates and Humphreys 2000) and urban and regional planning (e.g., Chapin 2004). The formation of dedicated research teams comprised of specialists in strategic management, stadium finance, political science, and public policy could improve our understanding of how various stakeholders (e.g., policymakers, citizens, sports organizations) position themselves within the stadium finance debate, and could therefore be valuable to representatives of any of those group. 


\section{References}

Abramowitz, A.I., 2013. The electoral roots of America's dysfunctional government. Presidential studies quarterly, 43, 709-731.

Ahn, S.C. and Lee, Y.H., 2014. Major League Baseball attendance: Long-term analysis using factor models. Journal of sports economics, 15, 451-477.

Allison, P.D., 2001. Missing data. Thousand Oaks, CA: Sage.

American National Election Studies, 2012a. The ANES guide to public opinion and electoral behaviour. Ann Arbor, MI: University of Michigan, Center for Political Studies.

Arnold, J.R. 2012. The electoral consequences of voter ignorance. Electoral studies, 31, 796815.

Bélanger, A. 2000. Sport venues and the spectacularization of urban spaces in North America: The case of the Molson Centre in Montreal. International review for the sociology of sport, 35, 378-397.

Blair, J.P. and Swindell, D.W., 1997. Sports, politics, and economics: The Cincinnati story. In: R.G. Noll and A. Zimbalist, eds. Sports, jobs and taxes: The economic impact of sports teams and stadiums. Washington, DC: The Brookings Institution Press, 282-323.

Brader, T., 2006. Campaigning for hearts and minds. Chicago, IL: University of Chicago Press.

Brown, C. and Paul, D.M., 2002. The political scorecard of professional sports facility referendums in the United States, 1984-2000. Journal of sport and social issues, 26, 248-267.

Buist, E.A. and Mason, D.S., 2010. Newspaper framing and stadium subsidization. American behavioral scientist, 53, 1492-1510.

Caldwell, W.W., 2006. Cynicism and the evolution of the American dream. Washington, DC: Potomac Books, Inc. 
Chaney, P., 2015. Electoral discourse and the party politicization of sport in multi-level systems: Analysis of UK elections 1945-2011. International journal of sport policy and politics, 7, 159-180.

Chapin, T.S., 2004. Sports facilities as urban redevelopment catalysts. Journal of the American Planning Association, 70, 193-209.

Clarey, C., 2014. Bidders are melting away. The New York Times, 29 May, p. B12.

Coates, D., 2007. Stadiums and arenas: Economic development or economic redistribution? Contemporary economic policy, 25, 565-577.

Coates, D. and Humphreys, B.R., 2000. The stadium gambit and local economic development. Regulation, 23 (2), 15-20.

Coates, D. and Humphreys, B.R., 2005. Novelty effects of new facilities on attendance at professional sporting events. Contemporary economic policy, 23, 436-455.

Collins, T.W., 2008. Unevenness in urban governance: Stadium building and downtown redevelopment in Phoenix, Arizona. Environment and planning C: Government and policy, 26, 1177-1196.

Crompton, J.L., 1995. Economic impact analysis of sports facilities and events: Eleven sources of misapplication. Journal of sport management, 9, 14-35.

Crompton, J.L., 2004. Beyond economic impact: An alternative rationale for the public subsidy of major league sports facilities. Journal of sport management, 18, 40-58.

Davis, Z., 2009. A phenomenology of political apathy: Scheler on the origins of mass violence. Continental philosophy review, 42, 149-169.

Dehring, C.A., Depken, C.A., and Ward, M.R., 2008. A direct test of the homevoter hypothesis. Journal of urban economics, 64, 155-170.

Delaney, K.J. and Eckstein, R., 2003. Public dollars, private stadiums: The battle over building sports stadiums. Rutgers, NJ: Rutgers University Press. 
DeVellis, R.F., 2012. Scale development: Theory and applications. 3rd ed. Los Angeles: Sage.

Dillman, D.A., Smyth, J.D., and Christian, L.M., 2008. Internet, mail, and mixed-mode surveys: The tailored design method. 3rd ed. Hoboken, NJ: John Wiley \& Sons, Inc.

Doherty, A., 2012. "It takes a village:" Interdisciplinary research for sport management. Journal of sport management, 26, 1-10.

Downs, A., 1957. An economic theory of democracy. New York: Harper and Row.

Emmerson, D.K., 2012. Minding the gap between democracy and governance. Journal of democracy, 23 (2), 62-73.

Erikson, R.S. and Tedin, K.L., 2010. American public opinion: Its origins, content, and impact. 8th ed. New York: Longman.

File, T. and Crissey, S. 2012. Voting and registration in the election of November 2008 [online]. U.S. Census Bureau. Available from: https://www.census.gov/prod/2010pubs/p20562.pdf [Accessed 30 June 2016].

Fort, R.D., 1999. Stadium votes, market power and politics. University of Toledo law review, 30, $419-441$.

Friedman, M. and Andrews, D. 2011. The built sport spectacle and the opacity of democracy. International review for the sociology of sport, 46, 181-204.

Friedman, M.T. and Mason, D.S., 2005. Stakeholder management and the public subsidization of Nashville's coliseum. Journal of urban affairs, 27, 93-118.

Grimes, M. and Esaiasson, P., 2014. Government responsiveness: A democratic value with negative externalities? Political research quarterly, 67, 758-768.

Groothuis, P.A., Johnson, B.K., and Whitehead, J.C., 2004. Public funding of professional sports stadiums: public choice or civic pride? Eastern economic journal, 30, 515-526.

Groves, R.M., et al., 2004. Survey methodology. Hoboken, NJ: John Wiley \& Sons. 
Haggman, M. and Brannigan, M., 2011. In dramatic revolt, Miami-Dade voters fire Mayor Carlos Alvarez over pay hikes, tax increases. The Miami Herald, 15 March.

Hanks, D., 2013. Miami Marlins attendance reverts to old Sun Life Stadium levels. Miami Herald, 2 August.

Harder, J. and Krosnick, J.A., 2008. Why do people vote? A psychological analysis of the causes of voter turnout. Journal of social issues, 64, 525-549.

Held, D., 2006. Models of democracy. 3rd ed. Stanford, CA: Stanford University Press.

Hetherington, M.J. and Husser, J.A., 2012. How trust matters: The changing political relevance of political mistrust. American journal of political science, 56, 312-325.

Horn, B.P., Cantor, M., and Fort, R. 2015. Proximity and voting for professional sporting stadiums: The pattern of support for the Seahawk stadium referendum. Contemporary economic policy, 33, 678-688.

Johnson, J.A. 2004. The impact of item characteristics on item and scale validity. Multivariate Behavioral Research, 39, 273-302.

Johnson, B.K., Groothuis, P.A., and Whitehead, J.C., 2001. The value of public goods generated by a major league sports team: The CVM approach. Journal of sports economics, 2, 6-21.

Kellison, T.B. and Kim, Y.K., 2014. Marketing pro-environmental venues in professional sport: Planting seeds of change among existing and prospective consumers. Journal of sport management, 28, 34-48.

Kellison, T.B. and Mondello, M.J., 2012. Organisational perception management in sport: The use of corporate pro-environmental behaviour for desired facility referenda outcomes. Sport management review, 15, 500-512.

Kellison, T.B. and Mondello, M.J., 2014. Civic paternalism in political policymaking: The justification for no-vote stadium subsidies. Journal of sport management, 28, 162-175. 
Kim, W. and Walker, M., 2012. Measuring the social impacts associated with Super Bowl XLIII: Preliminary development of a psychic income scale. Sport management review, 15, 91108.

Kim, Y.K., Trail, G.T., and Ko, J.K., 2011. The influence of relationship quality on sport consumption behaviours: An empirical examination of the relationship quality framework. Journal of sport management, 25, 576-592.

Kimes, M., 2014. Hushed money. ESPN The Magazine, 8 December, p. 12.

Kowal, J., 2006. As Sonics pack to leave town, Seattle shrugs. The New York Times, 13 November.

Little, R.J.A., 1988. A test of missing completely at random for multivariate data with missing values. Journal of the American Statistical Association, 83, 1198-1202.

Lo, Y., Mendell, N.R., and Rubin, D.B., 2001. Testing the number of components in a normal mixture. Biometrika, 88, 767-778.

Long, J.G., 2013. Public/private partnerships for major league sports facilities. New York: Taylor \& Francis.

Magleby, D.B., 1984. Direct legislation: Voting on ballot propositions in the United States. Baltimore, MD: The Johns Hopkins University Press.

Mardia, K.V., 1985. Mardia's test of multinormality. In: S. Kotz \& N. L. Johnson, eds. Encyclopedia of statistical sciences. vol. 5. New York: Wiley, 217-221.

Mondello, M.J. and Kellison, T.B., 2016. Sport stadium referendums: Factors influencing the success or failure of ballot initiatives. Journal of contemporary athletics, 10, 139-155.

Mondello, M.J., Schwester, R.W., and Humphreys, B.R., 2009. To build or not to build: Examining the public discourse regarding St. Petersburg's stadium plan. International journal of sport communication, 2, 432-450. 
Muthén, L.K. and Muthén, B. O., 2012. Mplus (version 7.0)[Computer software]. Los Angeles: Muthén \& Muthén.

Office of Management and Budget., 2015. Analytical perspectives, budget of the United States Government, fiscal year 2016. Washington, DC: U.S. Government Printing Office.

Pietryka, M.T. and Boydstun, A.E., 2012. Going maverick: How candidates can use agendasetting to influence citizen motivations and offset unpopular issue positions. Political behaviour, 34, 737-763.

Pinkleton, B.E., et al., 2012. Perceptions of news media, external efficacy, and public affairs apathy in political decision making and disaffection. Journalism \& mass communication quarterly, 89, 23-39.

Podsakoff, P.M., MacKenzie, S.B., and Podsakoff, N.P., 2012. Sources of method bias in social science research and recommendations on how to control it. Annual review of psychology, $63,539-569$.

Raykov, T. and Marcoulides, G.A., 1999. On desirability of parsimony in structural equation model selection. Structural equation modeling, 6, 292-300.

Recall Mayor Alvarez, 2011. Reason \#3 - \$2.4 billion to fund baseball stadium [Video file]. Available from: http://youtu.be/SXlOAWjXzrM [Accessed 30 June 2016].

Reid, G., 2014. Save Meadowbank stadium: The politics of local stadium closure. International journal of sport policy and politics, 6, 37-54.

Rosenberg, M., 1951. The meaning of politics in mass society. Public opinion quarterly, 15, 515.

Sam, M.P. and Scherer, J., 2006. The steering group as policy advice instrument: A case of “consultocracy" in stadium deliberations. Policy sciences, 39, 169-181.

Santo, C.A., 2007. Beyond the economic catalyst debate: Can public consumption benefits justify a municipal stadium investment? Journal of urban affairs, 29, 455-479. 
Satorra, A. and Bentler, P.M., 2001. A scaled difference chi-square statistics for moment structure analysis. Psychometrika, 66, 507-514.

Savalei, V., 2010. Expected versus observed information in SEM with incomplete normal and nonnormal data. Psychological methods, 15, 352-367.

Sam, M.P. and Scherer, J. 2010. Fitting a square stadium into a round hole: A case of deliberation and procrastination politics. Sport in society: Cultures, commerce, media, politics, 13, 1469-1485.

Scherer, J. and Sam, M.P., 2008. Public consultation and stadium developments: Coercion and the polarization of debates. Sociology of sport journal, 25, 443-461.

Schoon, I. and Cheng, H., 2011. Determinants of political trust: A lifetime learning model. Developmental psychology, 47, 619-631.

Schwester, R.W., 2007. An examination of the public good externalities of professional athletic venues: Justifications for public financing? Public budgeting \& finance, 27 (3), 89-109.

Shugan, M.S., 2002. Marketing science, models, monopoly models, and why we need them. Marketing science, 21, 223-228.

Sinclair, B., Hall, T.E., and Alvarez, R.M., 2011. Flooding the vote: Hurricane Katrina and voter participation in New Orleans. American politics research, 39, 921-957.

Smith, D.A. and Tolbert, C.J., 2004. Educated by initiative: The effects of direct democracy on citizens and political organizations in the American states. Ann Arbor, MI: University of Michigan Press.

Sonck, N. and Loosveldt, G., 2010. Impact of poll results on personal opinions and perceptions of collective opinion. International journal of public opinion, 22, 230-255.

Soroka, S.N. and Wlezien, C., 2015. The majoritarian and proportional visions and democratic responsiveness. Electoral studies, 40, 539-547. 
Thompson, W.E. and Horton, J.E., 1960. Political alienation as a force in political action. Social forces, 38, 190-195.

Tutka, P. and Seifried, C., 2015. The historical ideal-type as a heuristic device for academic storytelling by sport scholars. Quest, 67, 17-29.

Useem, B. and Useem, M., 1979. Government legitimacy and political stability. Social forces, 57, $840-852$.

Van Boven, L., Judd, C.M., and Sherman, D.K., 2012. Political polarization projection: Social projection of partisan attitude extremity and attitudinal processes. Journal of personality and social psychology, 103, 84-100.

Vossler, C.A. and Kerkvliet, J., 2003. A criterion validity test of the contingent valuation method: Comparing hypothetical and actual voting behaviour for a public referendum. Journal of environmental economics and management, 45, 631-649.

Warwick, P.V. 2015. Public opinion and government policy in Britain: A case of congruence, amplicfication or dampening? European journal of political research, 54, 61-80.

Winfree, J.A. and Rosentraub, M.S., 2012. Sports finance and management: Real estate, entertainment, and the remaking of the business. Boca Raton, FL: CRC Press.

Woods, S., 2006. Public opinion poll question databases: An evaluation. Journal of academic librarianship, 33, 41-46.

Zygmont, Z.X. and Leadley, J.C., 2005. When is the honeymoon over? Major League Baseball attendance 1970-2000. Journal of sport management, 19, 278-299. 


\begin{tabular}{|c|c|c|c|}
\hline $\begin{array}{c}\text { Perceived } \\
\text { Stadium Impact }\end{array}$ & & $\begin{array}{c}\text { Team } \\
\text { Attendance } \\
\text { Intentions }\end{array}$ & \\
\hline & $\begin{array}{c}\text { Support of } \\
\text { Financing Plan }\end{array}$ & & $\begin{array}{c}\text { Political } \\
\text { Apathy }\end{array}$ \\
\hline $\begin{array}{l}\text { Trust in Civic } \\
\text { Paternalistic } \\
\text { Leadership }\end{array}$ & & $\begin{array}{c}\text { Congruence } \\
\text { with Electorate }\end{array}$ & \\
\hline & & & $\begin{array}{c}\text { Voting } \\
\text { Intentions }\end{array}$ \\
\hline
\end{tabular}

Figure 1. A nomological network of PROPSA constructs. Solid lines correspond to Proposition 1, dashed lines to Proposition 2, and dotted lines to Proposition 3. 
Table 1

Measurement properties of PROPSA items

\begin{tabular}{|c|c|c|c|c|}
\hline & $\lambda$ & $S E$ & $\rho$ & AVE \\
\hline Perceived Arena Impact & & & .89 & .62 \\
\hline [The stadium] creates jobs for the community. & .74 & .03 & & \\
\hline [The stadium] brings business to the city. & .81 & .02 & & \\
\hline Because of [the stadium], the [district] has grown. & .81 & .02 & & \\
\hline [The stadium] has elevated the city's status compared to other cities. & .75 & .03 & & \\
\hline There is more energy in [city name] because of [the stadium]. & .83 & .03 & & \\
\hline Trust in Civically Paternalistic Leadership & & & .93 & .77 \\
\hline $\begin{array}{l}\text { I generally believe that local political leaders strive to maximize the } \\
\text { public benefit. }\end{array}$ & .84 & .03 & & \\
\hline I think local leaders act in the best interests of the people. & .90 & .02 & & \\
\hline $\begin{array}{l}\text { I believe local leaders act after considering the best interests of the } \\
\text { people. }\end{array}$ & 91 & .02 & & \\
\hline Local political leaders act in ways that make the community better. & .85 & .02 & & \\
\hline Support of Financing Plan & & & .97 & .90 \\
\hline I support the [plan] to finance [the stadium]. & .91 & .01 & & \\
\hline I am in favour of the [plan] to finance [the stadium]. & .97 & .01 & & \\
\hline $\begin{array}{l}\text { Using [source of public funds] to finance [the stadium] is an idea I can } \\
\text { endorse. }\end{array}$ & .97 & .01 & & \\
\hline $\begin{array}{l}\text { Financing [the stadium] with [source of public funds] is a favourable } \\
\text { plan. }\end{array}$ & .96 & .01 & & \\
\hline Team Attendance Intentions & & & .96 & .93 \\
\hline I intend to attend a [team] game whenever the season starts. & .98 & .01 & & \\
\hline I will attend a [team] game whenever the season starts. & .95 & .01 & & \\
\hline Congruence with the Electorate & & & .95 & .83 \\
\hline $\begin{array}{l}\text { I think the majority of [voters] supported the [public financing of the } \\
\text { stadium]. }\end{array}$ & .95 & .01 & & \\
\hline $\begin{array}{l}\text { Most [city or county] residents agreed with the [public financing of the } \\
\text { stadium]. }\end{array}$ & .96 & .01 & & \\
\hline $\begin{array}{l}\text { The [public financing of the stadium] is something that most people in } \\
\text { [the city or county] wanted. }\end{array}$ & .86 & .02 & & \\
\hline $\begin{array}{l}\text { The majority of the community agreed with the decision [to finance the } \\
\text { stadium] using [public funds]. }\end{array}$ & .88 & .02 & & \\
\hline Political Apathy & & & .77 & .58 \\
\hline Staying informed about the government is too much trouble. & .78 & .05 & & \\
\hline Keeping up on political issues takes too much time. & .86 & .03 & & \\
\hline Participating in elections is more trouble than it's worth. & .63 & .05 & & \\
\hline Voting Intentions & & & .91 & .72 \\
\hline I intend to vote the next time there is an election. & .82 & .08 & & \\
\hline The likelihood that I will vote in the next election is high. & .78 & .06 & & \\
\hline I will vote in the next election. & .85 & .04 & & \\
\hline I plan to vote in the next election. & .95 & .02 & & \\
\hline
\end{tabular}

Note. $\lambda=$ standardized factor loading. $S E=$ standard error. $\rho=$ construct reliability. AVE $=$ average variance extracted. 
PUBLIC ATTITUDES TOWARD NO-VOTE SUBSIDIES

Table 3

Squared inter-construct correlations

\begin{tabular}{lccccccc}
\hline & 1 & 2 & 3 & 4 & 5 & 6 & 7 \\
\hline 1. Impact & 1.00 & & & & & & \\
2. Trust & $.52^{*}$ & 1.00 & & & & & \\
3. Plan & $.60^{*}$ & $.50^{*}$ & 1.00 & & & & \\
4. Attend & $.46^{*}$ & $.10^{*}$ & $.39^{*}$ & 1.00 & & & \\
5. Congruent & $.51^{*}$ & $.52^{*}$ & $.73^{*}$ & $.23^{*}$ & 1.00 & & \\
6. Apathy & -.04 & -.06 & $.14^{*}$ & .07 & $.15^{*}$ & 1.00 & \\
7. Vote & $.15^{*}$ & .12 & -.02 & -.05 & -.03 & $-.47^{*}$ & 1.00 \\
\hline$* p<.05$. & & & & & & &
\end{tabular}

